\title{
PENGARUH DAYA TARIK WISATA, KESELAMATAN, DAN SARANA WISATA TERHADAP KEPUASAN SERTA DAMPAKNYA TERHADAP LOYALITAS WISATAWAN :
}

\author{
Studi Community Based Tourism di Gunung Api Purba Nglanggeran
}

\author{
Hary Hermawan \\ email: haryhermawan8@gmail. \\ Dosen Sekolah Tinggi Pariwisata ARS Internasional Bandung \\ com
}

Abstract

Loyalty has become a serious concern for the managers of tourist villages because the loyalty of tourists is a guarantee of tourism business to be sustainable. The purpose of this study is to examine how the loyalty of tourists can be created by the factors of the tourist attraction, safety, and amenities, with loyalty as an intervening, on the model of Community-Based Tourism development in Gunung Api Purba Nglanggeran Tourism Village. The analytical method used is path analysis with Partial Least Square (PLS). The results showed that the tourist attraction is a dominant factor that gives a positive influence on the loyalty of tourists through intervention variable satisfaction. Other factors studied, namely safety and tourist facilities are not proven to affect the loyalty of tourists. This research recommends that loyalty of tourists can be achieved through efforts to improve the quality of tourist attraction.

Keyword : tourist attraction, safety, amenities, satisfaction, loyalty

\section{PENDAHULUAN}

Kinerja kepariwisataan di Daerah Istimewa Yogyakarta menunjukan kenaikan jumlah kunjungan wisata cukup besar, yaitu $\mathbf{4 7 2 . 3 0 0 ~ w i s a t a w a n ~ p e r ~ t a h u n . ~}$ Akan tetapi, kenyataanya desa wisata belum mendapatkan proporsi kunjungan yang memuaskan dibanding kunjungan ke destinasi bentuk lain (Statistik Kepariwisataan, 2015). Bahkan beberapa desa wisata yang saat ini mengalami mati suri (travel.detik.com, diakses 30 Mei 2017).

Community Based Tourism (CBT) merupakan alternatif konsep pengelolaan desa wisata yang dianggap pro bagi kesejahteraan masyarakat lokal, karena pengelolaan sepenuhnya berada dalam kekuasaan masyarakat lokal itu sendiri (Inayatullah dalam Darmawi, 2010). Permasalahan yang sering terjadi di lapangan adalah mayoritas desa wisata masih dikelola oleh masyarakat yang kurang kompeten. Sehingga, produk-produk wisata yang dihasilkan kurang memuaskan.

Pengembangan pariwisata di Yogyakarta selalu dihantui masalah klasik tentang kurangnya inovasi maupun konsep-konsep baru masih menjadi persoalan dalam pengembangan daya tarik destinasi. Otonomi daerah memberikan kewenangan kepada masingmasing kabupaten/ kota menimbulkan persaingan bauran produk yang tidak terspesialisasi (Prihatno, 2010). Daya tarik wisata cenderung asal jadi, padahal kualitas daya tarik wisata merupakan faktor kunci yang paling menentukan minat wisatawan untuk mengunjungi destinasi (Basiya \& Rozak, 2012); (Sopyan \& Widiyanto, 2015); dan (Nasution et al., 2009). Kurangnya spesialisasi atau diversiasi daya tarik wisata antar desa wisata menjadi faktor yang membuat wisatawan enggan untuk berkunjung.

Perhatian pengelola terhadap aspek keselamatan wisatawan di desa wisata juga diduga menjadi faktor yang menyebabkan kurangnya minat berkunjung, padahal salah satu syarat desa wisata yang baik adalah jaminan keamanan dan keselamatan (Hadiwijoyo dalam Prabowo dkk., 2016). Jaminan keselamatan merupakan faktor utama yang menentukan tumbuh dan berkembangnya suatu destinasi wisata, serta termasuk nilai keunggulan yang akan menentukan kualitas sebuah destinasi wisata (Chiang, 2000). Tanpa jaminan keselamatan, destinasi wisata tidak akan mampu bersaing di pasar wisata (Adom dkk, 2012).

Aspek ketiga yang sering menjadi keluhan wisatawan terhadap pengembangan desa wisata adalah minimnya kondisi sarana wisata yang disediakan, padahal sarana wisata merupakan salah satu faktor penentu kepuasan (Soebiyantoro, 2009). Sarana pendukung yang disediakan pengelola desa wisata mayoritas masih dibuat ala kadarnya, kurang terawat, bahkan terkadang tidak sesuai dengan kebutuhan dan keinginan wisatawan yang sebenarnya, contoh masalah umum di destinasi wisata adalah toilet yang dibiarkan sangat kotor padahal dalam pemakaianya wisatawan selalu dipungut biaya perawatan.

Kondisi-kondisi pengelolaan desa wisata seperti diatas jika dibiarkan saja tentu akan menambah persepsi buruk calon wisatawan terhadap pengelolaan desa wisata. Kondisi pengelolaan yang buruk menyebabkan wisatawan tidak puas, pastinya juga tidak akan loyal. Sehingga wajar dengan berbagai kondisi tersebut membuat desa wisata kalah bersaing di pasar parwisata dibanding destinasi lain. 
Ditengah fenomene desa wisata yang lesu, ternyata kondisi serupa tidak nampak dalam pengelolaan Desa Wisata Nglanggeran yang mengandalkan Kawasan Gunung Api Purba sebagai daya tarik utamanya. Community Based Tourism (CBT) di Gunung Api Purba (Desa Wisata Nglanggeran) telah terbukti berhasil membawa desa wisata ini tetap eksis, indikatornya adalah capaian kunjungan wisata yang dari tahun ke tahun terus meningkat (Hermawan, 2016b).

Inovasi-inovasi baru dalam pengembangan Gunung Api Purba diindikasi sebagai faktor utama yang memperngaruhi kepuasan serta loyalitas wisatawan di Gunung Api Purba Nglanggeran. Setiap pengembangan daya tarik wisata, keselamatan, dan sarana pendukung wisata yang dikelola merujuk pada prinsip-prinsip Community Based Tourism (CBT) dengan membawa nilai-nilai kearifan sosial-budaya yang ada (Hermawan, 2016a).

Berdasarkan latar belakang tersebut, peneliti tertarik untuk mengkaji lebih jauh mengenai sejauh mana daya tarik wisata, keselamatan, dan sarana wisata yang dikembangkan dengan Community Based Tourism (CBT) di Gunung Api Purba mampu menciptakan kepuasan berwisata, serta bagaimana dampaknya terhadap loyalitas wisatawan.

\section{LITERATUR REVIEW}

\section{Community Based Tourism (CBT)}

Pariwisata berbasis masyarakat atau Community Based Tourism (CBT), merupakan pengembangan pariwisata dengan tingkat keterlibatan masyarakat setempat yang tinggi dan dapat dipertanggung jawabkan dari aspek sosial dan lingkungan hidup (CIFOR dalam Hayati, 2016) dan (Darmawi, 2010). Masyarakat membutuhkan pengakuan atas karya mereka, kreativitas mereka, dan mereka mengharapkan wisatawan dapat memberikan pengakuan atas produk-produk yang mereka hasilkan (Hermantoro, 2014).

World Wide Found for Nature (WWF) menyatakan Community Based Tourism (CBT) sebagai "Form of tourism where the local community has a substantial control over and involvement in its development and management; and a major proportional of the benefits remain within the community." Jika diartikan secara bebas pariwisata berbasis masyarakat juga dapat dimaknai sebagai penyediaan produk, jasa, ilmu pengetahuan dan keterampilan yang dapat ditemukan di dalam komunitas lokal, serta ditawarkan oleh pelaku/ steakholder lokal sendiri ("Kyrgyz Community Based Tourism,” n.d., diakses tanggal 15 Agustus 2016).

Cox dalam Pitana (2009) mengatakan bahwa "Pembangunan dan pengembangan pariwisata didasarkan pada kearifan lokal dan special local sense yang merefleksikan keunikan peninggalan budaya dan keunikan lingkungan." Oleh karena itu, setiap pengembangan destinasi yang dilakukan hendaknya mengadopsi konten yang mencerminkan nilai-nilai kearifan lokal, termasuk dalam pengembangan daya tarik wisata, keselamatan, serta sarana wisatanya. Community Based Tourism (CBT) dianggap sebagai wadah yang cocok untuk mewujudkan desa wisata yang berkualitas dan berkelanjutan. Masyarakat lokal dapat terus berkarya sesuai karakternya, dan wisatawan dapat menikmatinya. Dengan begitu, karya-karya masyarakat lokal mampu menambah kekayaan destinasi, sedangkan wisatawan dapat menikmatinya hingga puas, kemudian diharapkan akan berdampak pada loyalitas wisatawan tersebut dalam berwisata.

\section{Daya Tarik Wisata (Attraction)}

Menurut Undang-Undang Republik Indonesia Nomor 10 Tahun 2009, daya tarik wisata dapat dijelaskan sebagai segala sesuatu yang memiliki keunikan, keindahan, dan nilai yang berwujud keanekaragaman kekayaan alam, budaya, dan hasil buatan manusia yang menjadi sasaran atau tujuan kunjungan wisata. Secara lebih spesifik disebutkan bahwa daya tarik wisata alam, merupakan segala sesuatu yang memiliki keunikan, keindahan, keaslian, dan nilai yang berupa keanekaragaman kekayaan alam yang menjadi sasaran atau tujuan kunjungan wisatawan. Damanik dan Weber (2006) menekankan pentingnya keaslian dalam menentukan kualitas daya tarik wisata, baik dari segi originalitas, maupun otentisitasnya.

Desa Wisata Nglanggeran merupakan desa wisata yang mengandalkan daya tarik alam berupa Kawasan Gunung Api Purba Nglanggeran.

Oleh karena itu pengembangan daya tarik wisata Gunung Api Purba mengacu pada kriteria pengembangan daya tarik wisata alam seperti disebutkan diatas.

\section{Keselamatan (Safety)}

Pengelolaan keselamatan wisata akan selalu terkait dengan upaya-upaya meminalkan risiko dan kecelakaan.

Risiko didefinisikan sebagai sumber-sumber yang mengandung unsur perusak yang potensial bagi wisatawan, operator atau destinasi, dan komunitas. Elemen-elemen risiko dilihat dari siapa atau apa yang terkena dampak, atau apa yang mengalami kerugian dari setiap keadaan yang mengandung bahaya. Elemenelemen tersebut termasuk : manusia, lingkungan, fasilitas, infrastruktur, sarana umum, dan ekonomi (AICST, 2006). Risiko secara umum adalah segala sesuatu yang dapat terjadi pada diri manusia yang tidak diharapkan muncul. Semua kegiatan manusia pada dasarnya akan memiliki risiko meskipun kegiatan tersebut bertujuan untuk mencapai kesenangan saja (Yudistira \& Susanto, 2012).

Sedangkan kecelakaan didefinisikan sebagai kejadian yang tidak diinginkan, yang dapat menimbulkan cidera, kematian, kerugian, dan kerusakan pada property. Kecelakaan dapat terjadi karena kondisi simultan dari faktor manusia, faktor lingkungan, dan faktor alam sendiri (AICST, 2006).

Dalam Guidelines for safe recreational water (2003) disebutkan bahwa pencegahan resiko kecelakaan dapat 
dilakukan dengan peningkatan keselamatan. Peningkatan keselamatan tersebut dapat diintervensi dengan 5 pendekatan yaitu : 1. Pekerjaan/ perekayasaan (engineering); 2.Memperkuat (enforment); 3. Pendidikan (education); 4. Tindakan untuk memberanikan (encouragement); dan 5 . Kesiapan bahaya (emergency preparadness).

Pengelola destinasi wisata yang mengandung risiko tinggi wajib memperhatikan keselamatan pengunjung dengan perencanaan dan pengendalian risiko, seperti diamanahkan dalam Undang-Undang Republik Indonesia No 10Tahun, 2009 Pasal 26.

Desa Wisata Nglanggeran merupakan desa wisata yang mengadalkan wisata alam Kawasan Gunung Api Purba Nglanggeran serta aktifitas petualangan pendakian sebagai daya tarik wisata utamanya. Petualangan merupakan kegiatan yang sengaja mencari risiko dan ketidakpastian hasil. Dalam wisata petualangan komersial, risiko dan ketidakpastian harus dikelola erat jika tidak dapat dihilangkan (Ewert dkk dalam Entwistle, 1923).

\section{Sarana Wisata (Amenities)}

Fasilitas atau sarana wisata adalah elemen dalam suatu destinasi yang memungkinkan wisatawan tinggal di destinasi tersebut untuk menikmati atau berpartisipasi dalam atraksi yang ditawarkan (Suharto, 2016).

Baud Bovy dan Lawson (1998) mengatakan bahwa amenitas/sarana wisata merupakan semua bentuk fasilitas yang memberikan pelayanan bagi wisatawan untuk segala kebutuhanya selama tinggal di daerah tujuan wisata.

Sarana wisata sebenarnya tidak langsung terkait dengan pariwisata, tetapi sering menjadi bagian dari kebutuhan wisatawan. Amenitas fungsinya adalah memenuhi kebutuhan wisatawan selama tinggal untuk sementara waktu di daerah wisata yang dikunjungi. Salah satu faktor yang dapat mendorong wisatawan untuk melakukan kegiatan wisata yaitu adanya sarana wisata yang memberikan kemudahan berwisata.

\section{Kepuasan}

Kepuasan wisatawan adalah tingkat perasaan seseorang setelah membandingkan kinerja atau hasil yang dirasakan dibandingkan dengan harapannya (Kotler dan Makens, 1999).

Dalam bukunya yang lain, Kotler (2002) mendefinisikan kepuasan sebagai perasaan senang atau kecewa seseorang yang muncul setelah membandingkan antara persepsi/ kesannya terhadap kinerja (atau hasil) suatu produk dan harapan-harapannya. Kepuasan tentang daya tarik wisata dibandingkan dengan harapan wisatawan sebelum berkunjung di daya tarik wisata tersebut.

Daya tarik wisata, keselamatan, dan sarana wisata sebagai varibel penentu kepuasan dapat dikaji dengan pendekatan control attribution theory. Control attribution theory merupakan aspek-aspek yang dalam kendali dan tanggung jawab manusia, yang dapat diupayakan pengelola untuk lebih baik (Hasan, 2008). Dengan asumsi bahwa dampak kecelakaan akibat faktor yang sebenarnya dapat dicegah lebih mengecewakan daripada kecelakaan akibat risiko alam yang tidak dapat diduga atau diantisipasi oleh pengelola sebelumnya.

Loyalitas

Loyalitas pelanggan merupakan perilaku yang terkait dengan merek sebuah produk, termasuk kemungkinan memperbaharui kotrak merek di masa yang akan datang, berupa kemungkinan pelanggan merubah dukunganya terhadap merek, atau berupa kemungkinan pelanggan untuk meningkatkan citra positif suatu merek produk. Namun jika produk dianggap tidak memuaskan pelanggan, pelanggan akan bereaksi dengan cara exit (pelanggan menyatakan berhenti membeli merek atau produk) dan voice (pelanggan menyatakan ketidakpuasan secara langsung pada perusahaan) (Wallin Andreassen \& Lindestad, 1998).

Secara umum, loyalitas dimaknai sebagai komitmen pelanggan untuk berlangganan atau membeli ulang produk/jasa terpilih secara konsisten (Hurriyati, 2005); (Selang, 2013); (Hasan, 2008).

Sedangkan Kartajaya dan Setiawan (2014) menyatakan bahwa loyalitas tertinggi dilihat dari keaktifan pelanggan dalam merekomendasi brand. Namun, sering kali rekomendasi juga menjadi hal yang bias. Faktanya sering kali kita mendengar rekomendasi dari rekan yang berupa rekomendasi negatif.

Kesimpulanya, meskipun pembelian ulang dan rekomendasi adalah suatu hal yang sangat penting bagi pemasar, pemahaman loyalitas hanya pada indikator pembelian ulang dan rekomendasi terkadang tidak cukup, karena pelanggan yang membeli ulang dan menyebar berita belum tentu mempunyai sikap positif terhadap barang atau jasa yang di beli. Pembelian ulang tidak hanya terjadi karena puas, melainkan mungkin karena terpaksa atau suatu sebab lainya. Begitu juga tindakan menyebar berita mengenai suatu brand atau rekomendasi, rekomendasi juga bisa berupa rekomendasi negatif. Hal ini tidak termasuk dimensi loyalitas, melainkan hanya loyalitas semu/bias (Hasan,2008) dan (Irawan, 2012).

Loyalitas pelanggan yang sejati dapat tercipta jika pelanggan menjadi pembela (advokat) bagi perusahaan tanpa insentif sekalipun (Selang, 2013). Maka dalam menghindari bias oleh loyalitas semu, dalam pencarian data ditekankan dengan pernyataan "dengan senang hati” sebagai bentuk ungkapan tanpa keterpaksaan.

\section{Penelitian Terdahulu}

Daya tarik wisata terbukti secara empiris sebagai faktor yang menentukan kepuasan dan loyalitas wisatawan terhadap sebuah destinasi (Naidoo dkk., 2011); (Adom, Jussem, Pudun, \& Azizan, 2012); (Basiya \& Rozak, 2012); (Soebiyantoro, 2009) dan (Darsono, 2015). 
Penelitian Ayob dan Masroni (2014) dengan pendekatan kualitatif, menemukan fakta bahwa jika wisatawan merasa tidak aman dan jiwanya terancam akan tidak puas dan cenderung menumbuhkan kesan negatif terhadap destinasi wisata. Hasil penelitian lain menemukan bahwa keselamatan merupakan faktor utama yang menjadi pertimbangan wisatawan untuk memutuskan memilih destinasi wisata yang akan dikunjungi (Pizam dan Mansfeld, 1996); (Adom et al., 2012); dan (Chiang, 2000).

Soebiyantoro (2009) menemukan bahwa ketersediaan sarana wisata dan atraksi yang ditampilkan memberikan dampak kepuasan bagi wisatawan. Begitu pula dengan hasil penelitian Setiawan (2016), serta hasil penelitian Ghani \& Brahmanto (2016) yang samasama menunjukan menunjukkan bahwa variabel daya tarik, sarana wisata, aksesibilitas, dan jasa menjadi faktor penentu tingkat kepuasan.

Penelitian Valle dkk (2006) dengan menggunakan metode Sturktur Equation Model (SEM), menemukan bahwa kepuasan berkontribusi positif terhadap loyalitas.

\section{Kerangka Pemikiran}

Berdasarkan hasil penelitian terdahulu, daya tarik wisata, keselamatan dan sarana wisata terbukti memiliki pengaruh dalam membentuk kepuasan dan loyalitas wisatawan. Sedangkan kepuasan terbukti secara signifikan berpengaruh terhadap loyalitas. Oleh sebab itu perlu dikembangkan kerangka pemikiran baru dengan menempatkan kepuasan sebagai intervening dalam pembentukan loyalitas wisatawan oleh faktor daya tarik wisata, keselamatan, dan sarana wisata. Adapun alur pemikiran digambarkan sebagai berikut

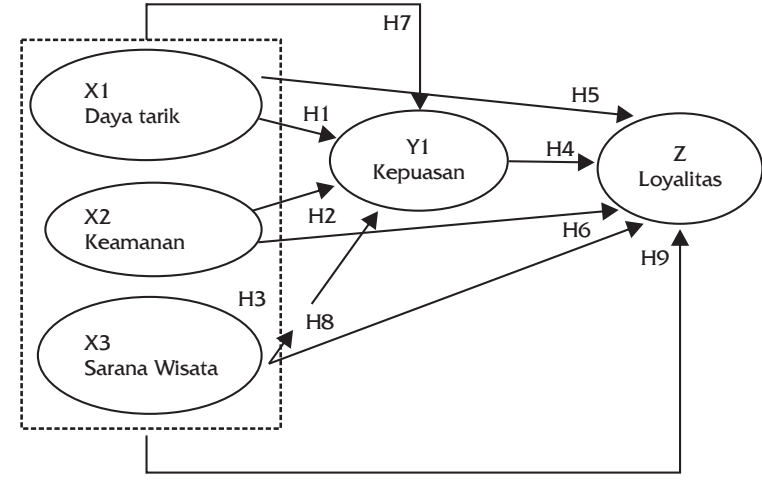

Hipotesis Penelitian

Berdasarkan kajian literatur, maka hipotesis alternatif penelitianya $(\mathrm{Ha})$ dirumuskan sebagai berikut :

1. Daya tarik wisata dengan CBT di Gunung Api Purba Nglanggeran berpengaruh terhadap kepuasan wisatawan

2. Keselamatan dengan CBT di Gunung Api Purba Nglanggeran berpengaruh terhadap kepuasan wisatawan

3. Sarana wisata dengan CBT di Gunung Api Purba Nglanggeran berpengaruh terhadap kepuasan wisatawan
4. Kepuasan berpengaruh terhadap loyalitas berwisata di Gunung Api Purba Nglanggeran

5. Daya tarik wisata dengan CBT di Gunung Api Purba Nglanggeran berpengaruh terhadap loyalitas berwisata

6. Keselamatan dengan CBT di Gunung Api Purba Nglanggeran berpengaruh terhadap loyalitas berwisata

7. Sarana wisata dengan CBT di Gunung Api Purba Nglanggeran berpengaruh terhadap loyalitas berwisata

8. Pengembangan Daya tarik wisata, keselamatan dan sarana wisata berpengaruh secara simultan terhadap kepuasan

9. Daya tarik wisata, keselamatan, sarana wisata, dan kepuasan berpengaruh secara simultan terhadap loyalitas

\section{METODOLOGI PENELITIAN}

Artikel ini merupakan kajian mengenai sejauh mana daya tarik wisata, keselamatan, dan sarana wisata yang dikembangkan dengan Community Based Tourism (CBT) mampu menciptakan kepuasan berwisata, serta dampaknya terhadap loyalitas wisatawan. Penelitian dilakukan di Gunung Api Purba, Desa Wisata Nglanggeran, Kabupaten Pathuk, Gunung Kidul, D.I.Yogyakarta.

Subjek yang menjadi sampel penelitian adalah wisatawan, sejumlah 100 wisatawan yang telah dipilih secara acak (acidencial sampling). Sedangkan yang menjadi objek studi adalah variabel independent: 1 . daya tarik wisata, 2 . keselamatan, dan 3 . sarana wisata. Variabel intervening kepuasan, sedangkan variabel dependent adalah loyalitas. Instrumen pencarian data adalah kuisionair dengan skala likert.

Desain penelitian adalah penelitian kuantitatif. Metode analisis jalur Partial Least Square (PLS) dipilih untuk menganalisis variabel independent daya tarik wisata ( $x 1)$, keselamatan $(x 2)$, sarana wisata $(x 3)$, dalam mempengaruhi variabel dependent loyalitas wisatawan (y2) melalui variabel intervening kepuasan (y1).

\section{HASIL DAN PEMBAHASAN}

Community Based Tourism di Gunung Api Purba Nglanggeran

Pariwisata di Gunung Api Purba Nglanggeran telah menjadi kegiatan masyarakat yang padat karya. Keseluruhan anggota pengelola tersebut merupakan masyarakat lokal Desa Nglanggeran sendiri, karena pengelolaan Desa Wisata Nglanggeran menganut prinsip-prinsip Community Based Tourism (CBT), yaitu pariwisata yang kepemilikan adalah komunitas lokal (Edi Darmawi, 2010); (Hermantoro, 2011); (Simanungkalit, 2015); dan (CIFOR dalam Hayati, 2016). Terbukti, Kelompok Sadar Wisata (Pokdarwis) Desa Wisata Nglanggeran yang berjumlah 169 anggota. Sebanyak 50 orang merupakan pengurus inti, sedang sisanya 
sebanyak 119 orang sebagai anggota (Hermawan, 2016).

Kesuksesan Community Based Tourism (CBT) di Desa Wisata Nglaggeran telah diakui secara luas. Pokdarwis Desa Wisata Nglaggeran saat ini telah mengoleksi berbagai piagam penghargaan tingkat nasional maupu internasional (Handoko, 2017a). Selain itu, Community Based Tourism (CBT) di Gunung Api Purba Nglanggeran mampu memberi dampak positif bagi ekonomi masyarakat lokal (Hermawan, 2016a), serta mampu meningkatkan kehidupan sosial-budaya masyarakatnya (Hermawan, 2016b).

Pariwisata berbasis masyarakat juga terefleksi dalam setiap langkah pengelolaan. Pengelolaan atraksi wisata, keselamatan, dan sarana wisata diduga peneliti sebagai faktor utama yang menentukan kepuasan serta berdampak kepada loyalitas wisatawan sehingga menghasilkan performa kunjungan wisatawan Gunung Api Purba Nglanggeran cenderung menunjukan trend peningkatan yang positif. Adapun pengelolaan pariwisata berbasis masyarakat di Gunung api Purba Ngalnggeran meliputi :

1. Pengeloalaan Daya Tarik Wisata

Daya tarik utama Kawasan Gunung Api Purba Nglanggeran adalah puncak-puncak gunung dengan pemandangan yang unik, otentik dan indah di dalam satu kawasan.

Masing-masing puncak memiliki keindahan, keunikan dan nilai historis dan nilai lokalitas yang memiliki nilai luhur tersendiri, baik nilai sejarah, mitologi dan filosofi (Handoko, 2017b). Daya tarik wisata tersebut meliputi : Gunung Kelir, Gunung Gedhe, Gunung Bongos, Gunung Blencong, Gunung Buchu. Ada juga fenomena serta bentang alam lain yang menjadi point of interest seperti Pemean Gadhung, Sumber Air Comberan, Tlogo Mardidho, Talang Kencana, dan lain sebagainya.

2. Upaya Keselamatan Berbasis Lokalitas

Jaminan pengelolaan keselamatan yang baik telah menjadi syarat yang wajib dipenuhi sesuai ASEAN Community Based Tourism Standart tahun 2016. Upayakan keselamatan wisata berbasis lokalitas di Gunung Api Purba Nglanggeran sebagai berikut :

a. Pembangunan (enginering)

Pembangunan keselamatan dengan penambahan penambahan pagar untuk pegangan pengunjung; perbaikan jalur tracking dan tangga pendakian yang berkarakter alam lokal; penambahan rambu penunjuk; rambu keamanan seperti batas aman pijakan di tebing; penanda arah jalur; penanda jalur evakuasi dan seterusnya yang semuanya dibuat dengan bahan dan desain bercorak lokal.

b. Memperkuat (Enforment)

Upaya enforment dilakukan dengan penambahan talut di beberapa area yang bentang alamnya miring untuk mencegah bahaya longsor. Upaya penguatan juga bertujuan untuk memperkuat kondisi

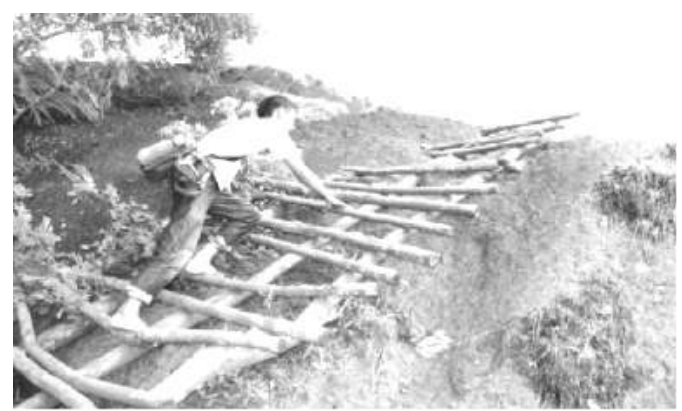

Gambar 1: Pembangunan Tangga Pendakian dengan Desain Lokal

(www.gunungapipurba.com, 18 April 2017)

lingkungan alam dan menambah daya dukung kawasan Gunung Api Purba Nglanggeran.

c. Pendidikan (Education)

Wisatawan cenderung merasa nyaman jika mengenal karakter lingkungan di destinasi wisata yang dikunjungi (Ross, 1998), oleh karena itu penngenalan lingkungan di kawasan wisata sangat perlu.

Simbol-simbol dan papan peringatan yang telah dibuat pengelola ditujukan untuk memberi edukasi diantaranya : penyediaan rambu petunjuk, papan informasi, peringatan, papan larangan, dan sebagainya yang dibuat berbasis lokalitas. Prinsip CBT yang menekankan lokalitas sebagai acuan dalam membangun segala unsur produk wisatanya.

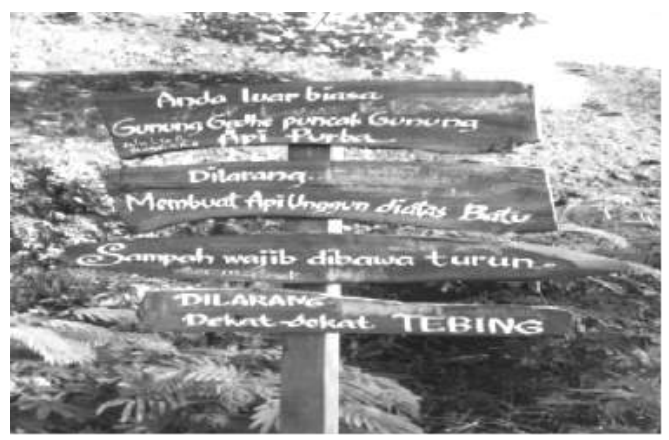

Gambar 2: Trend desain papan keselamatan dengan desain local (dokumentasi, 2017).

d. Tindakan untuk Memberanikan (Encouragement)

Tindakan untuk memberanikan (encouragement) di Gunung Api Purba Nglanggeran diimplementasikan dalam bentuk fasilitas keselamatan yang mampu membuat wisatawan merasa aman dan nyaman melakukan pendakian, contohnya pembuatan peta sebagai orientasi atau pengenalan karakter alam sekitar.

Informasi mengenai kondisi alam yang menjadi daya tarik wisata wajib diinformasikan kepada wisatawan. Oleh karena itu media informasi wajib disediakan tuan rumah wisata (ASEAN Community Based Tourism Standart, 2016). 


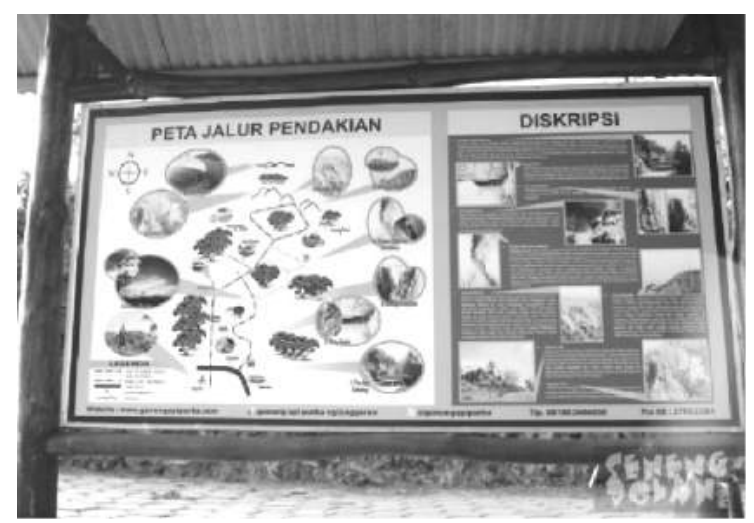

Gambar 3: Tindakan encouragement dengan peta destinasi (dokumentasi, 2017)

e. Kesiapan Bahaya (emergency preparadness)

Pengelola selalu siap siaga jika terjadi kondisi darurat dengan standar prosedur penanganan kecelakaan meliputi : 1) Naik melawati jalur evakuasi membawa korban cidera dengan drakbar untuk di bawa ke posko; 2) Memberikan pertolongan pertama oksigen dan obat-obatan yang diperlukan; 3) Penanganan lebih lanjut ke puskesmas jika diperlukan (Mursidi, wawancara 28 Desember 2016).

Kesiapan menghadapi risiko dan penanggulangan bahaya kecelakaan dilakukan dengan bekerjasama dengan Badan Sars Nasional (BASARNAS) secara periodik (Mursidi, wawancara 28 Desember 2016).

Tindakan kesiapan bahaya seperti diatas tidak setiap saat dapat diamati wisatawan. Oleh karena itu, kesiapan bahaya yang digunakan sebagai indikator penelitian adalah tindakan emergency preparadness yang langsung dapat diamati (observable). Tindakan kesiapan bahaya diamati dan diukur dalam penelitian ini adalah "Ada tidaknya pengelola yang terlihat siap-siaga di destinasi wisata untuk menjamin keselamatan wisatawan."

\section{Pengembangan Sarana Wisata}

Sarana wisata yang dikembangkan di Gunung Api Purba Desa Wisata Nglanggeran ditujukan untuk membantu memenuhi kebutuhan wisatawan selama berada di lokasi wisata. Sarana wisata yang dikembangkan dengan desain arsitektur lokal (Hermawan, 2016c), sesuai dengan prinsip-prinsip Community Based Tourism (CBT), yaitu ditujukan untuk melindungi kearifan lokal, serta lokalitas sebagai nilai jual (unique selling point) (Ainurrahman, 2010) dan (ASEAN Community Based Tourism Standart, 2016).

Pengembangan Sarana Wisata di Gunung Api Nglanggeran meliputi :
a. Pendapa atau Gasibu
b. Fasilitas Parkir
c. Toilet
d. Gardu Pandang
e. Warung Makan

f. Tempat Duduk Wisatawan di Beberapa Area

Hasil Penelitian

\section{Karakteristik Data Penelitian}

Responden dalam penelitian ini adalah wisatawan Gunung Api Purba Nglanggeran yang berjumlah 100 wisatawan. Karakteristik responden digunakan untuk mengetahui gambaran umum profil responden yang menjadi subjek penelitian.

Selain aspek demografi, karakteristik responden dalam penelitian ini juga merujuk pada tipologi wisatawan oleh I. G. Pitana \& Putu (2009), diantaranya : usia responden, jenis kelamin, asal wisatawan, dan motivasi berwisata di Gunung Api Purba Nglanggeran.

Karakteristik berdasarkan usia didominasi responden usia dewasa dengan presentase sebesar $76 \%$, kemudian disusul wisatawan usia paruh baya $18 \%$, dan terakhir usia remaja $6 \%$. Karakteristik usia early adhulthood memiliki pemikiran yang telah matang dalam berwisata, tidak tergesa-gesa atau penuh pertimbangan.

Hasil analisis karakteristik responden berdasarkan jenis kelamin, terlihat bahwa responden didominasi wanita sebesar $54 \%$, sedangkan responden pria sebesar $46 \%$.

Karakteristik responden berdasarkan motivasi terlihat bahwa $51 \%$ responden yang berwisata ke Gunung Api Purba Nglanggeran memiliki motivasi untuk melepas kejenuhan dari rutinitas kerja sehari-hari (leisure). Sedangkan sisanya sebanyak 49\% adalah wisatawan dengan motif petualangan (adventure/ drifter).

Sedangkan karakteristik data ditinjau berdasarkan daerah asal, menunjukan mayoritas responden merupakan wisatawan luar Yogyakarta 81\%. Responden yang berasal dari Yogyakarta diketahui sebesar 19\%.

Hasil Analisis Diskriptif

Daya Tarik Wisata

Hasil analisis deskriptif yang diolah berdasarikan persepsi 100 responden penelitiaan, menemukan 36\% pernyataan "sangat setuju" terhadap item pernyataan yang diajukan (5 item). Kemudian pernyataan "setuju" sebesar $54 \%$. Sedangkan pernyatan "netral sebesar $9 \%$. Terakhir hanya ditemukan sebanyak sebesar $1 \%$ pernyataan "tidak setuju".

Dari data diatas terlihat bahwa sebagian besar responden memiliki persepsi yang positif, atau dapat disimpulkan bahwa Gunung Api Purba Nglanggeran memiliki daya tarik wisata alam yang berkualitas.

\section{Keselamatan}

Hasil analisis deskriptif berdasarkan persepsi 100 responden, ditemukan sebesar $9 \%$ pernyataan "sangat setuju” terhadap keseluruhan item pernyataan yang diajukan (15 item). Serta sebesar $45 \%$ pernyataan "setuju." Pernyatan "netral," sebesar 29\%. Sedangkan pernyataan negatif "tidak setuju" ditemukan sebesar $14 \%$, disusul pernyataan "sangat tidak setuju" sebesar $3 \%$. 
Dari data diatas dapat disimpulkan bahwa kecenderungan pandangan responden terhadap keselamatan di Gunung Api Purba Nglanggeran adalah positif atau memenuhi standar keselamatan.

\section{Sarana Wisata}

Hasil analisis deskriptif berdasarkan persepsi 100 responden penelitiaan, menunjukan sebanyak $12 \%$ pernyataan "sangat setuju" terhadap keseluruhan item pernyataan yang diajukan (6 item). Kemudian juga diketahui terdapat 56\% pernyataan "setuju." Pernyatan "netral," diketahui sebesar 24\%. Pernyataan negatif "tidak setuju" ditemukan sebesar $8 \%$, sedangkan pernyataan "sangat tidak setuju" tidak ditemukan atau sebesar 0\%.

Dari data diatas dapat disimpulkan bahwa pandangan responden terhadap sarana wisata di Gunung Api Purba Nglanggeran adalah positif, dengan kata lain sarana wisata yang tersedia telah mampu memenuhi kebutuhan wisatawan.

Kepuasan Wisatawan

Berdasarkan hasil analisis diskriptif dari persepsi 100 responden menunjukan bahwa, sebesar $25 \%$ responden menyatakan "sangat setuju" terhadap keseluruhan item pernyataan yang diajukan. Kemudian juga diketahui terdapat 49\% pernyataan "setuju." Pernyatan "netral," diketahui terdapat sebesar $21 \%$, sedangkan pernyataan negatif "tidak setuju" ditemukan sebesar 3\% disusul pernyataan "sangat tidak setuju" sebesar $2 \%$. Kecenderungan data menunjukan mayoritas menunjukan sikap positif, maka ,dapat disimpulkan bahwa Gunung Api Purba Nglanggeran memuaskan wisatawan.

\section{Loyalitas Wisatawan}

Hasil analisis diskriptif dari persepsi 100 responden, menunjukan bahwa ditemukan sebesar $44 \%$ pernyataan "sangat setuju" terhadap keseluruhan item pernyataan yang diajukan (4 item). Kemudian ada $40 \%$ pernyataan "setuju". Pernyatan "netral," diketahui terdapat sebesar $17 \%$. Sedangkan pernyataan negatif "tidak setuju" dan "sangat tidak setuju" tidak ditemukan atau $0 \%$. Dari kecenderungan data mayoritas menunjukan sikap positif, maka dapat disimpulkan bahwa responden cukup loyal berwisata di Gunung Api Purba Nglanggeran .

Analisis Inferensial

1. Hasil Pengujian Outer Model

a. Validitas Convergen

Tabel 1: Validitas Convergen

\begin{tabular}{|c|c|c|c|c|c|c|c|}
\hline \multirow[b]{2}{*}{ Indikator } & \multicolumn{6}{|c|}{ Variabel laten (konstruk) } & \multirow{2}{*}{$\begin{array}{c}\text { Kesimpulan } \\
\text { Kes. }\end{array}$} \\
\hline & Kode & $x 1$ & $x 2$ & $x 3$ & y1 & $y^{2}$ & \\
\hline Keunikan & $X 1.1$ & 0,759 & & & & & Valid \\
\hline Keindahan & $\mathrm{X} 1.2$ & 0,819 & & & & & Valid \\
\hline Ke aslian & $X 1.3$ & 0,879 & & & & & Valid \\
\hline Nilai & $X 1.4$ & 0,847 & & & & & Valid \\
\hline Rekayasa & $X 2.1$ & & 0,804 & & & & Valid \\
\hline Memberanikan & $X 2.2$ & & 0,906 & & & & Valid \\
\hline Pendidikan & $X 2.3$ & & 0,607 & & & & Valid \\
\hline Kes. Bahaya & $X 2.4$ & & 0,556 & & & & Valid \\
\hline \multirow[t]{2}{*}{ Memperkuat } & $X 2.5$ & & 0,667 & & & & Valid \\
\hline & \multicolumn{5}{|c|}{ Variabel laten } & & Kesimpulan \\
\hline Gasibu & X3.1 & & & 0,667 & & & Valid \\
\hline Parkir & $\mathrm{X} 3.2$ & & & 0,722 & & & Valid \\
\hline Toilet & X3.3 & & & 0,738 & & & Valid \\
\hline Gardu pandang & X3.4 & & & 0,688 & & & Tidak Valid \\
\hline Warung makan & X3.5 & & & 0,578 & & & Tidak Valid \\
\hline Tempat duduk & X3.6 & & & 0,366 & & & Tidak Valid \\
\hline Kt. Daya tarik & Y1.1 & & & & 0,834 & & Valid \\
\hline Kt. Keselamatan & Y1.2 & & & & 0,846 & & Valid \\
\hline Kt. Sarana & Y1.3 & & & & 0,804 & & Valid \\
\hline Rekomendasi & Y2.1 & & & & & 0,944 & Valid \\
\hline Niat K Ulang & Y2.2 & & & & & 0,568 & Valid \\
\hline
\end{tabular}


Berdasarkan analisis convergen validity tabel 1 diatas, dapat dilihat bahwa seluruh indikator dari masingmasing konstruk dapat mengukur kunstuknya sendiri.

b. Validitas Diskriminan
Hal ini dapat dibuktikan dengan nilai outer loading seluruh indikator terhadap konstruknya lebih besar dari 0,5 .

Tabel 2: Validitas Diskriminan

\begin{tabular}{|c|c|c|c|c|c|c|c|}
\hline \multirow[b]{2}{*}{ Indikator } & \multicolumn{6}{|c|}{ Variabel laten } & \multirow[b]{2}{*}{ Kesimpulan } \\
\hline & Kode & $x 1$ & $x 2$ & $x 3$ & y1 & $y^{2}$ & \\
\hline Keunikan & $\mathrm{X} 1.1$ & 0.759 & 0.378 & 0.300 & 0.378 & 0.396 & Valid \\
\hline Keindahan & $X 1.2$ & 0.819 & 0.308 & 0.204 & 0.308 & 0.481 & Valid \\
\hline Keaslian & $X 1.3$ & 0.879 & 0.405 & 0.172 & 0.405 & 0.434 & Valid \\
\hline Nilai & $X 1.4$ & 0.847 & 0.428 & 0.368 & 0.428 & 0.648 & Valid \\
\hline Rekayasa & X2.1 & 0.344 & 0.804 & 0.246 & 0.255 & 0.312 & Valid \\
\hline $\begin{array}{l}\text { Memberanika } \\
\mathrm{n}\end{array}$ & $X 2.2$ & 0.559 & 0.906 & 0.261 & 0.488 & 0.337 & Valid \\
\hline Pendidikan & $X 2.3$ & 0.178 & 0.607 & 0.196 & 0.209 & 0.099 & Valid \\
\hline Kes. Bahaya & $X 2.4$ & 0.065 & 0.556 & 0.146 & 0.172 & 0.052 & Valid \\
\hline Memperkuat & $X 2.5$ & 0.125 & 0.667 & 0.352 & 0.091 & 0.023 & Valid \\
\hline Gasibu & X3.1 & 0.089 & 0.283 & 0.646 & 0.345 & 0.235 & Valid \\
\hline Parkir & X3.2 & 0.266 & 0.200 & 0.707 & 0.194 & 0.123 & Valid \\
\hline Toilet & X3.3 & 0.485 & 0.200 & 0.767 & 0.313 & 0.340 & Valid \\
\hline $\begin{array}{l}\text { Gardu } \\
\text { pandang }\end{array}$ & X3.4 & 0.312 & 071 & 0.715 & 0.136 & 0.185 & Valid \\
\hline $\begin{array}{l}\text { Warung } \\
\text { makan }\end{array}$ & X3.5 & -0.163 & 137 & 0.573 & 0.244 & -0.009 & Valid \\
\hline Kt. Daya tarik & Y1.1 & 0.667 & 0.257 & 0.273 & 0.834 & 0.607 & Valid \\
\hline $\begin{array}{l}\text { Kt. } \\
\text { Keselamatan }\end{array}$ & Y1.2 & 0.385 & 0.387 & 0.424 & 0.846 & 0.680 & Valid \\
\hline Kt. Sarana & Y1.3 & 0.248 & 0.422 & 0.229 & 0.804 & 0.386 & Valid \\
\hline Rekomendasi & Y2.1 & 0.625 & 0.260 & 0.237 & 0.696 & 0.944 & Valid \\
\hline Niat K Ulang & Y2.2 & 0.230 & 0.261 & 0.302 & 0.312 & 0.568 & Valid \\
\hline
\end{tabular}

Berdasarkan tabel diatas terlihat bahwa masing-masing indikator memiliki loading factor terhadap konstruknya sendiri yang besar dari pada dengan konstruk lain.
Dengan begitu dapat disimpulkan bahwa masingmasing indikator adalah valid, atau benar merupakan cerminan variabelnya sendiri.

c. Reliabilitas Konstruk

Tabel 3: Validitas Diskriminan

\begin{tabular}{lcl}
\multicolumn{1}{c}{ Variabel } & Reliability & Kriteria \\
\hline Dayatarik Wisata (X1) & 0.896 & Reliabel \\
Keselamatan ( X2) & 0.839 & Reliabel \\
Sarana Wisata ( X3) & 0.814 & Reliabel \\
Kepuasan ( Y1) & 0.867 & Reliabel \\
Loyalitas ( Y2) & 0.743 & Reliabel \\
\end{tabular}


Hasil analisis menunjukkan bahwa Composite Reliability pada semua konstruk telah mempunyai nilai yang memuaskan atau diatas nilai minimum 0,60 . Nilai tersebut menunjukkan konsistensi dan stabilitas indikator yang digunakan tinggi, sehingga dapat disimpulkan bahwa reliabilitas indikator masing-masing variabel terpenuhi.
2. Hasil Pengujian Inner Model

a. Koefisien determinasi RSquare (R2)

Analisis inferensial dilakukan berdasarkan hasil uji model struktural (Inner Model), pada hasil output R Square (R2) sebagai berikut :

Tabel 5: Koefisien Determinasi (R2)

\begin{tabular}{|c|c|c|}
\hline Variabel & R Square & R Square Adjusted \\
\hline Kepuasan (y1) & 0.375 & 0.355 \\
Loyalitas (y2) & 0.568 & 0.549 \\
\hline
\end{tabular}

b. Pengujian Hipotesis

Tabel 5: Koefisien Parameter dan P Value

\begin{tabular}{|c|c|c|c|c|}
\hline & Hipotesis & Koefisien & P-Value & Ket erangan \\
\hline $\mathrm{H} 1$ & $\begin{array}{l}\text { Daya tarik wisata }(x 1) \text { dengan CBT berpengaruh } \\
\text { terhadap kepuasan wisatawan }(y 1)\end{array}$ & 0.408 & 0.000 & Signifikan \\
\hline $\mathrm{H} 2$ & $\begin{array}{l}\text { Keselamatan wisata }(x 2) \text { dengan CBT } \\
\text { berpengaruh terhadap kepuasan }(y 1)\end{array}$ & 0.169 & 0.013 & Signifikan \\
\hline $\mathrm{H} 3$ & $\begin{array}{l}\text { Sarana wisata }(x 3) \text { dengan CBT berpengaruh } \\
\text { terhadap kepuasan wisatawan }(y 1)\end{array}$ & 0.201 & 0.031 & Signifikan \\
\hline $\mathrm{H} 4$ & $\begin{array}{l}\text { Kepuasan }(y 1) \text { berpengaruh terhadap loyalitas } \\
\text { berwisata }(y 2)\end{array}$ & 0.539 & 0.000 & Signifikan \\
\hline H5 & $\begin{array}{l}\text { Dayatarik wisata }(x 1) \text { dengan CBT berpengaruh } \\
\text { terhadap loyalitas berwisata }(y 2)\end{array}$ & 0.347 & 0.001 & Signifikan \\
\hline H6 & $\begin{array}{l}\text { Keselamatan }(x 2) \text { dengan CBT berpengaruh } \\
\text { terhadap loyalitas berwisata }(y 2)\end{array}$ & -0.073 & 0.440 & $\begin{array}{c}\text { Tidak } \\
\text { Signifikan }\end{array}$ \\
\hline $\mathrm{H} 7$ & $\begin{array}{l}\text { Sarana Wisata }(x 3) \text { dengan CBT berpengaruh } \\
\text { terhadap loyalitas berwisata }(y 2)\end{array}$ & -0.002 & 0.987 & $\begin{array}{c}\text { Tidak } \\
\text { Signifikan }\end{array}$ \\
\hline H8 & $\begin{array}{l}\text { Pengembangan daya tarik wisata }(x 1) \text {, } \\
\text { keselamatan }(x 2) \text { dan sarana wisata }(x 3) \text { dengan } \\
\text { CBT berpengaruh secara simultan terhadap } \\
\text { kepuasan berwisata }(y 1)\end{array}$ & 0.355 & 0.000 & Signifikan \\
\hline $\mathrm{H} 9$ & $\begin{array}{l}\text { Pengembangan daya tarik wisata }(x 1) \text {, } \\
\text { keselamatan }(x 2) \text { dan sarana wisata }(x 3) \text { dengan } \\
\text { CBT serta kepuasan }(y 1) \text { berpengaruh secara } \\
\text { simultan terhadap loyalitas berwisata }(y 2)\end{array}$ & 0.549 & 0.000 & Signifikan \\
\hline
\end{tabular}

c. Hasil Analisis Jalur

Analisis jalur dilakukan dengan menghitung pengaruh langsung (Direct Effect), pengaruh tidak langsung (Indirect Effect), serta pengaruh totalnya (Total Effect) seperti berikut: 


\begin{tabular}{|c|c|c|c|c|c|c|}
\hline Var & \multicolumn{2}{|c|}{$\mathrm{DE}$} & IE & \multicolumn{2}{|c|}{$\mathrm{TE}$} & Kesimpulan \\
\hline & Y1 & Y2 & Y2 & Y2 & Sig & \\
\hline 1 & 2 & 3 & 4 & $5=(3)+(4)$ & 6 & 7 \\
\hline $\mathrm{X} 1$ & 0.408 & 0.347 & 0.220 & 0.567 & 0.000 & $\begin{array}{l}\text { Intervening berperan, } \\
\text { signifikan pada } 95 \%\end{array}$ \\
\hline $\mathrm{X} 2$ & 0.169 & -0.073 & 0.091 & 0.018 & 0.864 & $\begin{array}{l}\text { Intervening berperan, tidak } \\
\text { signifikan pada } 95 \%\end{array}$ \\
\hline X3 & 0.201 & 0.002 & 0.108 & 0.107 & 0.280 & $\begin{array}{l}\text { Intervening berperan, tidak } \\
\text { signifikan pada } 95 \%\end{array}$ \\
\hline Y1 & & 0.539 & & & 0.000 & Signifikan pada $95 \%$ \\
\hline
\end{tabular}

DE : Direct Effeck

TE : Tottal Effeck

IE : In Direct Effeck

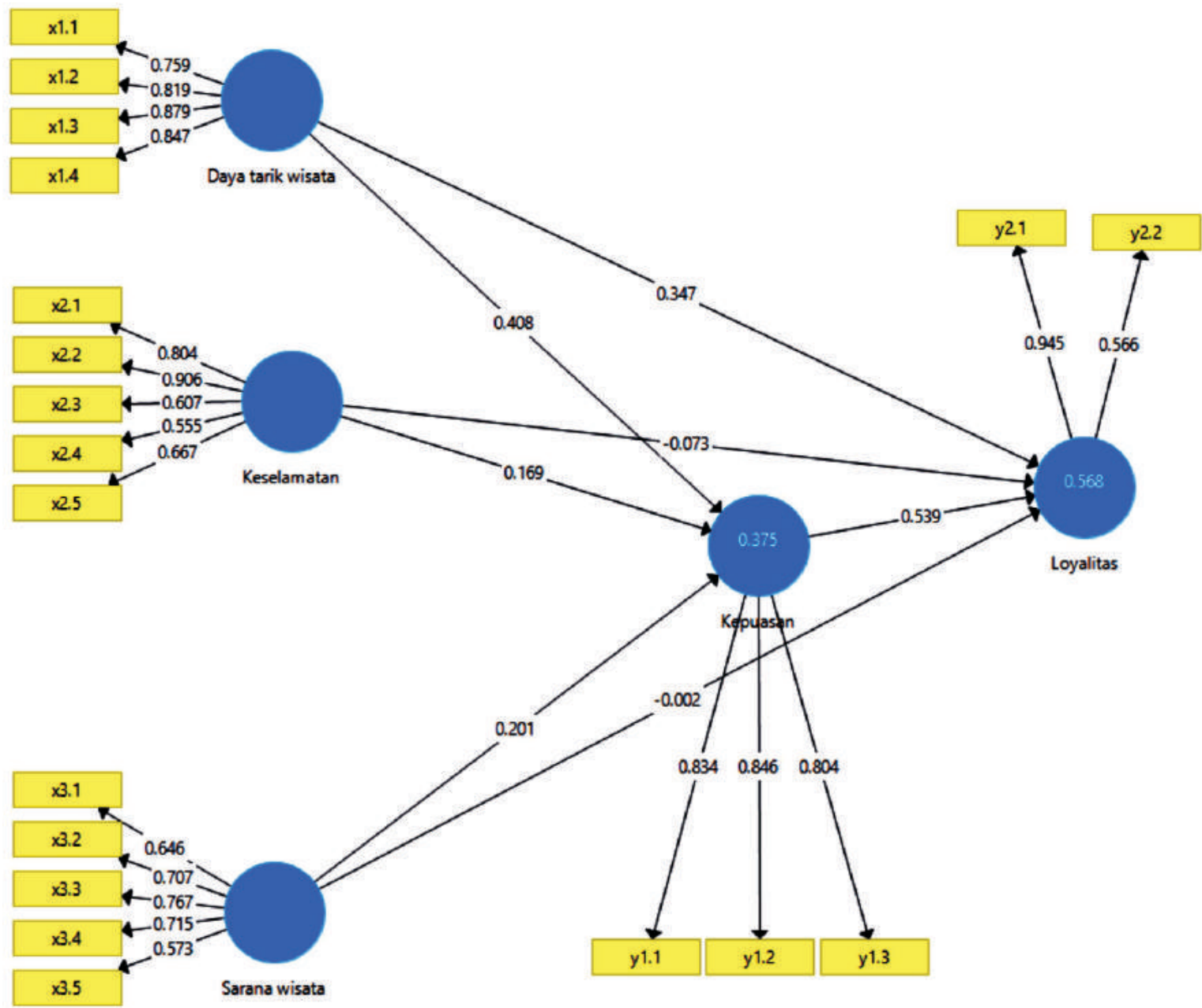

Gambar 4: Koefisien Jalur Setelah Uji Indikator (Data primer, 2017) 
Pembahasan

Analisis inferensial ditunjukan untuk menggali informasi bagaimana variabel terikat daya tarik wisata, keselamatan, dan sarana wisata yang dikelola masyarakat dengan prinsip-prinsip Community Based Tourism Development (CBT) dalam mempengaruhi kepuasan wisatawan, serta dampaknya terhadap loyalitas. Adapun hasil penelitian diuraikan sebagai berikut :

(H1) pengaruh daya tarik wisata dengan $C B T$ di Gunung Api Purba Nglanggeran terhadap kepuasan wisatawan

Daya tarik wisata berbasis Community Based Tourism (CBT) terbukti berpengaruh signifikan terhadap kepuasan wisatawan di Gunung Api Purba Nglanggeran. Hal ini dapat dibuktikan pada tabel 5 nilai P value 0.000 , jauh lebih kecil dari nilai alpha 0.05 pada taraf kepercayaan $95 \%$.

Hasil penelitian ini mendukung penelitan terdahulu yang telah dilakukan oleh Naidoo dkk (2011) yang menemukan bahwa daya tarik wisata berbasis alam berkontribusi dalam mempengaruhi kepuasan. Demikian juga dengan penelitian lain yang menyatakan bahwa daya tarik wisata berkontribusi positif dalam mempengaruhi kepuasan berwisata (Lesmana \& Brahmanto, 2016); (Rajesh, 2013). (Naidoo dkk., 2011); (Adom et al., 2012); (Basiya \& Rozak, 2012); dan (Darsono, 2015).

Nilai original sample variabel daya tarik wisata dalam mempengaruhi kepuasan adalah positif yaitu sebesar 0,408 yang menunjukkan bahwa arah hubungan antara $\mathrm{X} 1$ dengan $\mathrm{Y} 1$ adalah positif, Pengaruh positif tersebut juga dapat dibuktikan dengan hasil analisis diskriptif yang menunjukan persepsi responden terhadap daya tarik wisata yang positif, selaras dengan tingkat kepuasan responden yang berada pada tingkat puas. jika diinteprestasikan berarti "Semakin meningkat daya tarik wisata semakin meningkat pula kepuasan wisatawan di Gunung Api Purba Nglanggeran." Pengaruh positif juga dapat berarti sebaliknya, yaitu semakin menurun kualitas daya tarik wisata akan semakin menurun pula kepuasan wisatawan sehingga dikawatirkan akan berdampak pada menurunya minat kunjungan wisatawan seperti pada hasil penelitian terdahulu (Wiradiputra \& Brahmanto, 2016).

Hasil ini membuktikan betapa pentingnya pengelolaan daya tarik wisata dalam meningkatkan kepuasan wisatawan. Oleh karena itu dirasa tepat langkah pengembangan daya tarik wisata alam di Gunung Api Purba yang telah dilakukan pengelola dengan mengacu pada prinsip-prinsip Community Based Tourism (CBT). Prinsip menjunjung tinggi kearifan dalam CBT diharapkan mampu menghasilkan destinasi wisata yang unik serta bernilai lokal (lokal sense) sebagai sebuah keunggulan bersaing (Ainurrahman, 2010); menjamin keberlanjutan lingkungan; meningkatkan kebanggaan masyarakat lokal (Suansri dkk., 2013), serta yang utama pengembangan daya tarik dengan CBT terbukti mampu menjamin kepuasan wisatawan.
(H2) pengaruh upaya keselamatan wisata dengan CBT di Gunung Api Purba Nglanggeran terhadap kepuasan wisatawan

Upaya keselamatan wisata yang dikelola dengan CBT di Gunung Api Purba Nglanggeran berpengaruh terhadap kepuasan wisatawan, terbukti pada tabel 5, menunjukan $P$ value 0.013 , lebih kecil dari nilai alpha 0.05 pada taraf kepercayaan $95 \%$. Hasil penelitian ini sejalan dengan penelitian terdahulu yang menyatakan bahwa keselamatan berpengaruh positif terhadap kepuasan wisatawan (Adom dkk., 2012) dan (Ayob \& Masroni, 2014).

Nilai original sample adalah positif yaitu sebesar 0,169 yang menunjukkan bahwa arah hubungan antara $\mathrm{X} 2$ dengan $\mathrm{Y} 1$ adalah positif.

Pengaruh signifikan tersebut juga dapat dibuktikan dengan hasil analisis diskriptif yang menunjukan persepsi responden terhadap keselamatan cukup positif, selaras dengan tingkat kepuasan responden. Jika diinteprestasikan berarti "Meningkatkan keselamatan wisata akan berdampak pada meningkatnya kepuasan wisatawan di Gunung Api Purba Nglanggeran."

Jaminan keselamatan merupakan faktor yang menjadi pertimbangan wisatawan dalam memilih destinasi wisata yang akan dikunjungi (Pizam dan Mansfeld, 1996) dan (Chiang, 2000). Oleh karena itu, upaya peningkatan keselamatan dianggap sebagai upaya yang sangat tepat dalam menjamin kepuasan wisatawan terhadap destinasi wisata, disamping memberikan perlindungan terhadap risiko dan kecelakaan berwisata merupakan kewajiban pengelola (Suharto, 2016).

Pengembangan keselamatan dengan desain lokal yang dibuat unik dengan corak budaya terbukti dalam penelitian Wibowo (2015) lebih efektif daripada desain keselamatan yang hanya dibuat standar. Oleh karena itu, tepat jika upaya keselamatan yang dikembangkan di Gunung Api Purba Nglanggeran mengacu pada konsep Community Based Tourism (CBT), dengan desain yang dibuat unik, mengacu pada nilai-nilai lokal yang ada. Selain menjamin keselamatan wisatawan, keselamatan dengan CBT terbukti mampu meningkatkan kepuasan wisatawan, sehingga upaya keselamatan dengan CBT ini layak untuk dilanjutkan.

(H3) pengaruh sarana wisata dengan CBT di Gunung Api Purba Nglanggeran terhadap kepuasan wisatawan

Sarana wisata dengan CBT di Gunung Api Purba Nglanggeran berpengaruh terhadap kepuasan wisatawan. Terbukti pada tabel 5 nilai $P$ value 0.031 , lebih kecil dari nilai alpha 0.05 pada taraf kepercayaan 95\%.

Hasil penelitian diatas juga sejalan dengan hasilhasil penelitian terdahulu yang mempersentasikan bahwa sarana wisata yang ditampilkan mampu memberikan kepuasan bagi wisatawan (Soebiyantoro, 2009); (Salindri, 2016) serta (Ghani \& Brahmanto, 2016). 
Sedangkan nilai original sample adalah positif, yaitu sebesar 0,201 yang menunjukkan arah hubungan antara X3 dengan Y1 adalah positif. Pengaruh positif juga dapat dibuktikan pada analisis diskriptif yang menunjukan persepsi responden terhadap sarana wisata cukup positif, selaras dengan tingkat kepuasan responden. Jika diinteprestasikan berarti "Peningkatan penyediaan sarana wisata akan berdampak pada meningkatnya kepuasan wisatawan di Gunung Api Purba Nglanggeran."

Pembangunan sarana wisata yang tidak boleh terlalu kontras dari lingkungan alam dan sosial-budaya budaya masyarakat lokal sekitar agar tidak menjadikan polusi lansekap. Salah satu solusinya dengan pembangunan pariwisata merujuk pada kearifan lokal dan special local sense yang merefleksikan keunikan budaya dan keunikan lingkungan alam (Cox dalam Pitana, 2009). Mulai dari segi desain serta termasuk bahan-bahan yang digunakan dalam pembuatan sarana wisata yang ramah lingkungan dan budaya.

\section{(H4) kepuasan berpengaruh terhadap loyalitas}

Kepuasan wisatawan berpengaruh terhadap loyalitas berwisata di gunung. Terbukti pada 4 nilai $P$ value 0.000 , jauh lebih kecil dari nilai alpha 0.05 pada taraf kepercayaan 95\%. Hasil penelitian ini juga mendukung Penelitian yang menemukan bahwa kepuasan wisatawan berkontribusi positif terhadap loyalitas berwisata di destinasi (Valle dkk, 2006); (Prayag, 2008). Akan tetapi, hasil penelitian ini bertentangan dengan hasil penelitian Rahmawati dan Barustyawati (2009) yang menemukan bahwa tidak ada hubungan antara kepuasan wisatawan dengan loyalitas berwisata yang diukur dengan tingkat keinginan merekomendasikan destinasi wisata.

Nilai original sample adalah positif yaitu sebesar 0,539, menunjukkan bahwa arah hubungan antara $Y 1$ dengan $Y 2$ adalah positif. Pengaruh positif juga dapat dibuktikan pada analisis diskriptif yang menunjukan kepuasan wisatawan terhadap Gunung Api Purba Nglanggeran berada pada tingkatan puas, selaras dengan loyalitas responden yang cukup baik. Implikasinya, "Semakin meningkatkan kepuasan wisatawan akan semakin meningkat pula loyalitasnya untuk berwisata."

(H5) daya tarik wisata dengan CBT di Gunung Api Purba Nglanggeran berpengaruh terhadap loyalitas

Daya tarik wisata dengan CBT di Gunung Api Purba Nglanggeran berpengaruh terhadap loyalitas. Hasil ini dapat dibuktikan pada tabel 5 , nilai $P$ value 0.001 , jauh lebih kecil dari nilai alpha 0.05 pada taraf kepercayaan 95\%. Hasil diatas sejalan dengan hasil peneliti sebelumnya menemukan bahwa daya tarik wisata berkontribusi dalam mempengaruhi loyalitas (Naidoo dkk, 2011); (Bursan, 2006); dan (Rajesh, 2013).

Nilai original sample estimate adalah positif yaitu sebesar 0,347 yang menunjukkan bahwa arah hubungan antara X1 dengan Y2 adalah positif. Hal tersebut juga dapat dibuktikan dengan hasil analisis diskriptif yang menunjukan persepsi responden terhadap daya tarik wisata yang positif, selaras dengan nilai loyalitas wisatawan yang cukup baik. Konsekuensinya adalah "Semakin meningkatkan daya tarik wisata akan semakin meningkatkat pula loyalitas wisatawan di Gunung Api Purba Nglanggeran." Penelitian ini menunjukan bahwa pengelolaan daya taik wisata yang baik merupakan salah satu kunci dalam meningkatkan loyalitas berwisata.

Kualitas daya tarik wisata yang semakin unik, indah, serta terjaga keaslianya dan memiliki nilai mampu menjamin wisatawan loyal terhadap destinasi tersebut, dapat berupa kunjungan ulang atau setidaknya turut membantu merekomendasikan daya tarik wisata yang dikunjunginya. Meskipun pada kenyataanya konsep loyalitas pada industri pariwisata merupakan suatu hal yang sangat sulit untuk dipastikan karena wisatawan memiliki kebebasan absolut dalam melakukan perjalanan (L. A. Wibowo \& Yuniawati, 2007).

(H6) upaya keselamatan wisata dengan CBT tidak berpengaruh terhadap loyalitas wisatawan di Gunung Api Purba Nglanggeran

Penelitian ini menemukan bahwa tidak ada pengaruh keselamatan dengan CBT terhadap loyalitas wisatawan di Gunung Api Purba Nglanggeran. Hal ini dapat dibuktikan dalam tabel 5, nilai P value 0.440 , lebih besar dari nilai alpha 0.05 pada taraf kepercayaan $95 \%$.

Penelitian ini jelas bertentangan dengan hasil penelitian Ayob dan Masroni (2014) yang menyatakan bahwa keselamatan berpengaruh terhadap loyalitas. Begitu juga dengan penelitian Prayag (2008) yang menemukan bahwa atribut seperti keselamatan mempengaruhi loyalitas wisatawan.

Ketidak sesuaian dengan penelitian terdahulu dapat dimungkinkan akibat banyaknya wisatawan dengan karakter bermotif petualang sebanyak 49\%, seperti terlihat pada analisis karakteristik wisatawan. Dalam kajian literatur disebutkan bahwa wisatawan dengan motif petualang cenderung mengabaikan faktor risiko (keselamatan) dan lebih mengutamakan perolehan pengalaman berwisata (Entwistle, 1923). Wisatawan dengan motif petualang cenderung lebih mengutamakan keaslian daya tarik wisata, bahkan seorang berkarakter drifter cenderung memilih destinasi wisata yang belum dikelola, serta belum pernah dikunjungi orang lain (I. G. Pitana \& Putu, 2009). Walaupun keselamatan tebukti tidak berpengaruh signifikan terhadap loyalitas wisatawan, namun upaya keselamatan tetap harus diupayakan oleh pengelola destinasi wisata. Karena jaminan keselamatan wisatawan merupakan hal mendasar yang menjadi kewajiban pengelola wisata (Undang-Undang Republik Indonesia No 10 Tahun 2009 Tentang Kepariwisataan) dan (Undang-Undang Nomor 8 Tahun 1999 Tentang Perlindungan Konsumen, n.d.)

(H7) sarana wisata dengan CBT tidak berpengaruh terhadap loyalitas wisatawan di Gunung Api Purba Nglanggeran

Sarana wisata dengan CBT tidak berpengaruh signifikan terhadap loyalitas wisatawan di Gunung Api Purba Nglanggeran. Hal ini dapat dibuktikan dengan 
tabel 5 yang menunjukan nilai P value 0.987 , lebih besar dari nilai alpha 0.05 pada taraf kepercayaan $95 \%$.

Hasil penelitian ini jelas bertentangan dengan hasil penelitian terdahulu yang menyatakan bahwa sarana wisata berpengaruh langsung terhadap loyalitas (Prayag, 2008).

Banyaknya wisatawan petualang sebesar 49\% diduga menjadi penyebab sarana wisata tidak berpengaruh terhadap loyalitas. Dalam kajian literatur disebutkan bahwa wisatawan dengan motif petualang cenderung mengutamakan destinasi yang masih asli, tidak suka mengikuti jalan-jalan wisata yang sudah umum, serta cenderung mencari hal-hal yang tidak umum. Bahkan, disebutkan wisatawan berkarakter drifter, satu tingkat diatas petualang, justru memilih destinasi yang belum pernah dikunjungi orang lain (I. G. Pitana \& Putu, 2009).

(H8) daya tarik wisata, keselamatan, dan sarana wisata, yang dikelola dengan CBT berpengaruh secara simultan terhadap kepuasan wisatawan

Daya tarik wisata, keselamatan, serta sarana wisata yang dibangun dengan Community Based Tourism (CBT) secara bersama-sama terbukti mampu mempengaruhi kepuasan wisatawan. Hal ini dapat dibuktikan dari nilai $P$ value 0.000 , jauh lebih kecil dari nilai alpha 0.05 pada taraf kepercayaan 95\% sehingga hipotesis (H8) diterima. Hasil penelitian ini sejalan dengan penelitian Ihshani (2005), Naidoo dkk., (2011) dan Adom dkk., (2012) yang menunjukan menunjukkan bahwa variabel daya tarik, keselamatan dan sarana wisata secara simultan mempengaruhi tingkat kepuasan wisatawan.

Sedangkan nilai original sample menunjukan arah positif yaitu sebesar 0,355. Hasil ini juga dapat dibuktikan pada hasil analisis diskriptif variabel daya tarik wisata, keselamatan, serta sarana wisata yang masingmasing menunjukan kecenderungan nilai posistif selaras dengan variabel kepuasan wisatawan yang juga menunjukan nilai positif. Jika diinteprestasikan lebih dalam berarti "Upaya meningkatkan variabel daya tarik wisata, keselamatan dan sarana wisata secara bersamasama akan berdampak pada peningkatan tingkat kepuasan wisatwan Gunung Api Purba Nglanggeran sebanyak $35,5 \%$, sedang sisanya $65,5 \%$ dipengaruhi variabel lain diluar variabel yang diteliti."

(H9) daya tarik wisata, keselamatan, sarana wisata, serta kepuasan wisatawan, secara simultan berpengaruh terhadap loyalitas

Analisis hipotesis secara simultan membuktikan bahwa daya tarik wisata, keselamatan, sarana sisata, dan kepuasan (Y1) bersama-sama mempengaruhi loyalitas (Y2). Hal ini dapat dibuktikan dari nilai $P$ value 0.000 , jauh lebih kecil dari nilai alpha 0.05 pada taraf kepercayaan 95\% sehingga hipotesis (H9) diterima.

Hasil penelitian diatas mendukung penelitian Prayag (2008) menemukan bahwa sarana wisata, keselamatan, infrastruktur, atraksi/ daya tarik wisata, suasana, serta aksesibilitas mempengaruhi loyalitas wisatawan.

Sedangkan nilai original sample menunjukan arah positif yaitu sebesar 0,549. Jika diinteprestasikan berarti "Upaya meningkatkan variabel daya tarik wisata, keselamatan, sarana wisata dan kepuasan secara bersama-sama akan semakin meningkatkan loyalitas wisatawan berwisata di Gunung Api Purba Nglanggeran sebanyak $54,9 \%$, sedang sisanya $45,1 \%$ dipengaruhi variabel lain."

Dengan demikian maka meningkatkan ketiga variabel diatas menjadi variabel kunci dalam meningkatkan loyalitas wisatawan dalam berwisata. Daya tarik wisata merupakan alasan fundamental yang menjadi pertimbangan mengapa seseorang memilih satu destinasi dan meninggalkan destinasi yang lain (Crouch dan Ritchie dalam Stevianus, 2014). Daya tarik wisata dianggap sebagai motivasi utama wisatawan untuk melakukan perjalan wisata (Suryadana, 2015). Upaya keselamatan sebagai upaya menjamin kondisi ideal destinasi yang akan menjamin wisatawan betah dan nyaman berwisata. Sedangkan sarana wisata merupakan aspek pendukung yang memudahkan serta membantu memenuhi kebutuhan wisatawan selama menikmati destinasi. Ketiga variabel tersebut merupakan variabel kunci dalam pengembangan desa wisata.

Pembahasan Hasil Analisis Jalur

Daya tarik wisata secara langsung berpengaruh terhadap loyalitas sebesar 0,347. Sedangkan, jika melalui variabel kepuasan pengaruhnya sebesar 0,567 dengan taraf signifikansi 0,000 jauh lebih kecil daripada nilai alpha 0,05 pada taraf kepercayaan $95 \%$.

Kepuasan sebagai variabel intervening terlihat mampu memberi kontribusi peningkatan pengaruh positif variabel daya tarik wisata terhadap kepuasan secara signifikan. Hal ini menunjukan bahwa kepuasan memang berlaku sebagai faktor yang mengintervensi pengaruh daya tarik wisata terhadap loyalitas wisatawan, sehingga menghilangkan kemungkinan adanya loyalitas semu oleh wisatawan di Gunung Api Purba Nglanggeran (Desa Wisata Nglanggeran).

Hasil penelitian diatas melahirkan suatu solusi paktis bahwa meningkatkan kualitas daya tarik wisata di Gunung Api Purba Nglanggeran yang meliputi: keunikan, keindahan, keaslian, dan nilai akan berpengaruh terhadap peningkatan kepuasan wisatawan. Dampak dari wisatawan yang terpuaskan tersebut semakin meningkatkan loyalitas wisatawan dalam beriwisata di Gunung Api Purba Nglanggeran, baik dalam segi rekomendasi positif maupun niat wisatawan untuk berkunjung kembali.

Keselamatan wisata secara langsung tidak terbukti berpengaruh terhadap loyalitas karena nilai signifikansi 0,864 lebih besar daripada nilai alpha 0,05 pada taraf kepercayaan $95 \%$. Hal ini dapat dibuktikan juga dengan melihat nilai original yang hanya sebesar -0,073. Sedangkan pengaruh keselamatan terhadap loyalitas melalui intervening kepuasan sebesar 0,018.

Hasil diatas jelas menunjukan bahwa tidak terdapat pengaruh keselamatan loyalitas wisatawan dengan 
variabel intervening kepuasan. Keselamatan sebenarnya merupakan kebutuhan atau aspek mendasar dalam pengelolaan destinasi, yang kurang memiliki arti bagi wisatawan untuk dievaluasi pada kondisi normal walupun sebenarnya keselamatan merupakan aspek yang penting. Jika terjadi kecelakaan atau kondisi darurat baru kemungkinan pengelola akan menjadi kambing hitam atau aktor utama yang akan dipersalahkan. Walaupun begitu, jaminan keselamatan tetap merupakan hal yang wajib diupayakan pengelola dalam menjamin keselamatan wisatawan.

Sarana wsiata yang dikembangkan dengan Community Based Tourism (CBT) secara langsung tidak terbukti berpengaruh terhadap loyalitas karena nilai signifikansi 0,280 lebih besar daripada nilai alpha 0,05 pada taraf kepercayaan $95 \%$. Hal ini dapat dibuktikan juga dengan melihat nilai original yang hanya sebesar 0,002 . Sedangkan pengaruh keselamatan terhadap loyalitas melalui intervening kepuasan sebesar 0,107.

Hal diatas dapat dimaklumi karena segmen wisatawan sebanyak 49\% di Gunung api Purba Nglanggeran adalah wisatawan bermotif petualang adventure, sehingga lebih menuntut kepuasan pengalaman wisata berbasis tantangan serta kurang peduli dengan sarana wisata (I. G. Pitana \& Putu, 2009).

\section{Pembahasan Analisis Faktor Dominan}

Daya tarik wisata merupakan satu-satunya variabel eksogen yang terbukti signifikan mempengaruhi loyalitas wisatawan dibuktikan dengan $p$ value 0,000 jauh lebih kecil dari nilai alpha 0,05 pada taraf kepercayaan 95\%. Daya tarik wisata juga mempunyai nilai original sample paling tinggi yaitu sebesar 0,567 dibanding kedua variabel eksogen lain diantaranya : keselamatan (X2) hanya sebesar 0,018 dan sarana wisata (X3) sebesar 0,107.

Dengan demikian, dapat disimpulkan bahwa daya tarik wisata merupakan variabel paling dominan yang mempengaruhi kepuasan wisatawan di Gunung Api Purba Nglanggeran, dengan pola hubungan positif. Dengan demikian dapat disimpulkan bahwa kunci peningkatan loyalitas wisatawan Gunung Api Purba Nglanggeran adalah dengan meningkatkan daya tarik destinasinya.

\section{KESIMPULAN}

Loyalitas telah begitu lama menjadi perhatian para ahli pemasaran. Begitu juga dalam hal pariwisata, upaya untuk menciptakan loyalitas wisatawan juga menjadi perhatian serius para pengelola destinasi wisata. Wisatawan loyal yang berkunjung ulang dengan pembelanjaanya akan menambah pemasukan bagi destinasi secara kontinyu. Sedangkan rekomendasi positif akan menambah citra destinasi sehingga destinasi wisiata akan semakin dikenal di pasar wisata. Intinya, loyalitas wisatawan merupakan jaminan bagi bisnis pariwisata untuk terus berkelanjutan.

Hasil penelitian ini membuktikan bahwa kepuasan terbukti signifikan sebagai variabel yang mengintervensi faktor-faktor yang mempengaruhi loyalitas wisatawan di Gunung Api Purba Nglanggeran. Oleh karena itu, kunci dalam menciptakan loyalitas wisatawan dapat dicapai meningkatkan terlebih dahulu menaikan tingkat kepuasan wisatawan melalui peningkatan variabelvariabel bebasnya atau faktor-faktor penentu.

Faktor penentu paling dominan yang terbukti mempengaruhi kepuasan dan loyalitas dalam penelitian ini adalah daya tarik wisata, dengan pola hubungan positif, yang berarti bahwa dengan meningkatkan daya tarik wisata maka akan meningkatkan kepuasan wisatawan, sehingga berdampak pada tercapainya loyalitas wisatawan. Sedangkan faktor penenentu lain yang diuji, yaitu keselamatan dan sarana wisata hanya mampu mempengaruhi kepuasan, akan tetapi tidak terbukti signifikan mampu mempengaruhi loyalitas wisatawan, baik secara langsung maupun melalui perantara kepuasan.

Fenomena ini diduga terjadi karena segmen wisatawan di Gunung Api Purba yang merupakan wisatawan berkarakter petualang (adventure) cukup besar. Wisatawan petualang (adventure) yaitu wisatawan yang mencari kepuasan dari pengalaman yang penuh tantangan, serta cenderung senang mengambil risiko. Nihilnya pengaruh sarana wisata terhadap loyalitas, dapat dimungkinkan karena wisatawan Gunung Api Pruba Nglanggeran menganggap sarana wisata hanya sebagai pendukung pariwisata yang sudah umum, sehingga tidak menjadi pertimbangan wisatawan untuk loyal terhadap suatu destinasi.

Implikasi manajerial yang dapat diambil berdasarkan penelitian ini sebagai berikut:

Pengembangan Gunung Api Purba Nglanggeran difokuskan pada peningkatan daya tarik wisata alam kawasan Gunung Api Purba Nglanggeran. Pengelolaan pariwisata dengan Community Based Tourism (CBT) berdasarkan pada nilai-nilai lokal telah terbukti efektif dalam meningkatkan kunjungan wisatawan. Akan tetapi perlu diperhatikan juga bahwa kawasan Gunung Api Purba Nglanggeran merupakan daya tarik wisata alam yang ekslusif karena berada pada zona konservasi. Daya tarik wisata alam memiliki karakter yang mudah rusak, tidak dapat terganti dan diperbaharui. Oleh karena itu, sangat penting bagi pengelola untuk menerapkan langkah-langkah konservasi alam. Perlu juga dibuat berbagai aturan tegas sebagai langkah preventif untuk mencegah aksi penjarahan atau vandalisme yang dilakukan oleh oknum-oknum wisatawan.

Ditinjau dari perspektif pemasaran, penelitan ini menggambarkan betapa pentingnya pengelolaan kepuasan dan loyalitas wisatawan melalui manajemen daya tarik wisata alam yang baik. Manajemen daya tarik wisata alam yang baik dapat diwujudkan dengan langkah-langkah berikut : 1 . Mengemas potensi wisata alam dengan menonjolkan keunikanya sebagai nilai jual, dalam pemasaran dikenal dengan diversifikasi produk; 2. Menambah keindahan dengan merawat dan 
menata ulang kawasan sebagai point of interest, menonjolkan sisi-sisi eksotisme alam Nglanggeran; 3. Menjaga keaslian dan kealamiahan lingkungan alam, dengan tidak melakukan pembangunan yang terlalu kontras dengan lingkungan alam sekitar, sehingga tidak terjadi polusi pemandangan maupun kerusakan ekositem alam; 3. Melanjutkan pengelolaan dengan CBT yang mengakngkat nilai budaya lokal atau lokalitas kemudian direfleksikan secara komprehensif dalam setiap pengemasan daya tarik wisata, sehingga akan menambah nilai atau daya jual (value of sellling) destinasi.

Meskipun keselamatan tidak berpengaruh terhadap loyalitas wisatawan, tetapi jaminan keselamatan merupakan tanggung jawab yang harus terus diwujudkan di destinasi wisata seperti diamanahkan dalam Undang-Undang Nomor 10 Tahun 2009 Tentang Kepariwisataan dan Undang-Undang Nomor 8 Tahun 1999Tentang Perlindungan Konsumen.

Sarana wisata terbukti tidak begitu signifikan dalam mempengaruhi kepuasan wisatawan, bahkan sarana wisatawan tidak ada hubunganya sama sekali dengan loyalitas wisatawan di Gunung Api Purba Nglanggeran. Oleh karena itu, minimalisasi pembangunan sarana wisata di Gunung Api Purba Nglanggeran merupakan langkah yang bijak, dalam mendukung konservasi alam Nglanggeran yang memiliki ekosistem serta keanekaragaman hayati yang dilindungi. Penting untuk evaluasi zonasi, kawasan mana yang boleh dibangun sarana wisata, serta kawasan mana yang menjadi area inti pencagaran. Zonasi ini sebaiknya juga diinformasikan kepada wisatawan agar wisatawan dapat memahaminya.

\section{REFERENSI}

Adom, Y. A., Jussem, B., Pudun, J., \& Azizan, Y. (2012). Factors that Influence Visitor's Satisfaction Toward Kuching Waterfront. Journal for the Advancement of Scient \& Art, 45.

AICST, A. (2006). Plan of Action for Sustainable Tourism Management in Asia and the Pacific. Phase II (20062012)

Ainurrahman. (2010). Wisata berbasis komunitas. Karsa, 18(2), 136-146.

ASEAN Community Based Tourism Standart. (2016). Jakarta: ASEAN Secretariat. Retrieved from public@asean.org

Ayob, N. M., \& Masroni, T. (2014). Issues of Safety and Security: New Challenging to Malaysia Tourism Industry. In SHS Web of Conferences (Vol. 12, pp. $1-10)$.

Basiya, R., \& Rozak, H. A. (2012). Kualitas Daya Tarik Wisata, Kepuasan dan Niat Kunjungan Kembali Wisatawan Mancanegara di Jawa Tengah. Jurnal Ilmiah Dinamika Kepariwisataan, 11(2).

Baud-Bovy, M., \& Lawson, F. (1998). Tourism and recreation: handbook of planning and design. Butterworth-Heinemann Ltd.
Bursan, R. (2006). Analisis Pengaruh Dimensi Wisata Terhadap Loyalitas Wisatawan (Studi Kasus di Propinsi Lampung). Bisnis \& Manajemen, 1 .

Chiang, L. C. (2000). Strategies for safety and security in tourism: a conceptual framework for the Singapore hotel industry. Journal of Tourism Studies, 11(2), 44.

Damanik, J., \& Weber, H. F. (2006). Perencanaan Ekowisata dari Teori ke Aplikasi. diterbitkan atas kerjasama Pusat Studi Pariwisata (PUSPAR) Universitas Gadjah Mada dan Penerbit Andi. Yogyakarta.

Darsono, R. (2015). Pengaruh Kualitas Daya Tarik Wisata terhadap Tingkat Kepuasan Wisatawan, Studi Kasus di Waduk Jatiluhur-Kabupaten Purwakarta. Jurnal Nasional Pariwisata, 5(1), 14-22.

Edi Darmawi. (2010). Pengembangan Kepariwisataan Berbasis Masyarakat di Kota Bengkulu. Jurnal Ilmiah IDEA (Vol. 4). Bengkulu: Fakultas Ilmu Sosial dan IImu Politik UMB Bengkulu.

Entwistle, W. J. (1923). The Adventure of" Le Cerf au Pied Blanc" in Spanish and Elsewhere. The Modern Language Review, 18(4), 435-448.

Ghani, Y. A., \& Brahmanto, E. (2016). engaruh Inovasi Sarana Prasarana Terhadap Kepuasan Pengunjung di Objek Wisata Karangsetra Waterland. Jurnal Pariwisata, 2(2), 98-110.

Guidelines for safe recreational water. Volume 1, coastal and fresh waters. (2003). Risk Management (Vol. 1).

Handoko, S. (2017a). Desa Wisata Nglanggeran Memperoleh Penghargaan CBT ASEAN di Singapore. Retrieved April 3, 2017, from http://www.gunungapipurba.com/posts/detail/de sa-wisata-nglanggeran-memperoleh-peghargaancbt-asean-di-singapore

Handoko, S. (2017b). Gunung Api Purba Nglanggeran. Retrieved April 3, 2017 , from www.gunungapipurba.com

Hasan, A.2008. Marketing. Yogyakarta : Media Presindo

Hermantoro, H. (2014). Creative-Based Tourism: Dari Wisata Rekreatif Menuju Wisata Kreatif. Lap Lambert Academic Publishing.

Hermawan, H. (2016a). Dampak Pengembangan Desa Wisata Nglanggeran Terhadap Ekonomi Masyarakat Lokal. Jurnal Pariwissata, III(2).

Hermawan, H. (2016b). Dampak Pengembangan Desa Wisata Nglanggeran Terhadap Sosial Budaya Masyarakat Lokal. In Seminar Nasional Ilmu Pengetahuan dan Teknologi Komputer Nusa Mandiri Pertama Tahun 2016 (Vol. 1, pp. 426-435). SNIPTEK Nusa Mandiri.

Hurriyati, R. (2005). Bauran Pemasaran dan Loyalitas Pelanggan. Bandung: Alfabeta.

Ihshani, D. W. (2005). Analisis Kepuasan Konsumen Terhadap Atribut Wisata Cangkuang Garut, Jawa Barat. IPB (Bogor Agricultural University). Retrieved from http://repository.ipb.ac.id/handle/123456789/11 549 
Irawan, C. (2012). Secangkir Kopi untuk Sahabat Customer. Jakarta: Prima grafika.

Kartajaya, H., \& Setiawan, I. (2014). Wow Marketing. Gramedia Pustaka Utama.

Kotler, P. (2002). Manajemen Pemasaran, terjemahan Hendra Teguh, edisi Millenium, cetakan pertama (1st ed.). Jakarta: Prenhalindo.

Kotler, P., \& Makens, J. C. (1999). Marketing for Hospitality and Tourism, 5/e. Pearson Education India.

Kyrgyz Community Based Tourism. (2017). Retrieved from www.cbtkyrgyztan.kg

Lesmana, A. A., \& Brahmanto, E. (2016). Pengaruh Atraksi Wisata Terhadap Kepuasan Pengunjung Primata Schmutzer Taman Margasatwa Ragunan Jakarta. Jurnal Pariwisata, 2(2), 121-128.

Naidoo, P., Ramseook-Munhurrun, P., \& Seegoolam, P. (2011). An Assessment of Visitor Satisfaction with Nature-Based Tourism Attractions.

Nasution, S., Nasution, M. A., \& Damanik, J. (2009). Persepsi Wisatawan Mancanegara Terhadap Kualitas Objek dan Daya Tarik Wisata (ODTW) Sumatera Utara.

Pitana, I. (2009). Pengantar Ilmu Pariwisata. Yogyakarta: andi.

Pitana, I. G., \& Putu, G. (2009). Sosiologi Pariwisata. Yogyakarta: Andi.

Pizam, A., \& Mansfeld, Y. (1996). Tourism, crime, and international security issues. John Wiley \& Son Ltd.

Prabowo, S. E., Hamid, D., \& Prasetya, A. (2016). Analisis Partisipasi Masyarakat Dalam Pengembangan Desa Wisata: Studi Pada Desa Pujonkidul Kecamatan Pujon Kabupaten Malang. Jurnal Administrasi Bisnis, 33(2), 18-24.

Prayag, G. (2008). Image, satisfaction and loyalty-The case of Cape Town. Anatolia, 19(2), 205-224.

Prihatno, P. (2010). Memulihkan Citra Daerah Istimewa Yogyakarta untuk Meningkatkan Jumlah Wisatawan. Wahana Informasi Pariwisata: Media Wisata.

Rahmawati, P. I., Bis, S. S. P. M., \& Barustyawati, A. A. S. (2009). Evaluasi Tingkat Kepuasan Wisatawan Sebagai Pondasi Pengukuran Destination Competitiveness: Studi Empiris Dari Kawasan Wisata Lovina.

Rajesh, R. (2013). Impact of tourist perceptions, destination image and tourist satisfaction on destination loyalty: A conceptual model. Revista de Turismo Y Patrimonio Cultural, 11(3), 67-78.

Ross, G. F. (1998). Psikologi Pariwisata. Jakarta: Yayasan Obor Indonesia.

Selang, C. A. D. (2013). Bauran Pemasaran (Marketing Mix) Pengaruhnya Terhadap Loyalitas Konsumen pada Fresh Mart Bahu Mall Manado. Jurnal Riset Ekonomi, Manajemen Bisnis Dan Akuntansi, 1(3).

Simanungkalit, V. br dkk. (2015). Buku Panduan Pengembangan Desa Wisata Hijau. (C. Novianti, Ed.). Jakarta: Asisten Deputi Urusan Ketenagalistrikan dan Aneka Usaha Kementerian Koperasi dan UKM Republik Indonesia.
Soebiyantoro, U. (2009). Pengaruh ketersediaan sarana prasarana, sarana transportasi terhadap kepuasan wisatawan. Jurnal Manajemen Pemasaran, 4, pp.1622. https://doi.org/10.9744/pemasaran.4.1.pp. 1622

Sopyan, S., \& Widiyanto, I. (2015). Analisis Pengaruh Daya Tarik Wisata dan Kualitas Pelayanan Terhadap Minat Berkunjung Ulang Pengunjung dengan Kepuasan Pengunjung Sebagai Variabel Intervening (Studi pada Cagar Budaya Gedung Lawang Sewu). Fakultas Ekonomika dan Bisnis.

Statistik Kepariwisataan. (2015). D.I. Yogyakarta Indonesia: Dinas Pariwisata Daerah Istimewa Yog y a karta. Retrie ved from http://visitingjogja.web.id/assets/uploads/files/ban k_data/Buku_Statistik_Kepariwisataan_DIY_2015_0 5092016040516.pdf, diakses 5 Juni 2017

Stevianus, S. (2014). Pengaruh Atraksi Wisata, Fasilitas Dan Kualitas Pelayanan Terhadap Kepuasan Pengunjung Di Taman Margasatwa Ragunan Jakarta. Jurnal Ilmiah Ekonomi Bisnis, 19(3).

Suharto. (2016). Dengan , Hubungannya Destinasi, Citra Kasus, Studi Loka, Gembira. Jurnal Media Wisata, 14(1), 287-304.

Suryadana, M. V. O. (2015). Pengantar Pemasaran Pariwisata. Bandung Indonesia: Alfabeta.

Undang-Undang Nomor 10 Tahun 2009 Tentang Kepariwisataan, Sekretariat Negara. Jakarta § (2009). Indonesia.

Undang-Undang Nomor 8 Tahun 1999 Tentang Perlindungan Konsumen. Indonesia.

Valle, P. O. do, Silva, J. A., Mendes, J., \& Guerreiro, M. (2006). Tourist Satisfaction and Destination Loyalty Intention: A Structural and Categorical Analysis. International Journal of Business Science and Applied Management, 1(1), 25-44. Retrieved from h t t p : / / b u s i n e s s - a n d management.org/library/2006/1_1--25-44-Oom_do_Valle,Silva,Mendes,Guerreiro.pdf

Wallin Andreassen, T., \& Lindestad, B. (1998). Customer Loyalty and Complex Services: The Impact of Corporate Image on Quality, Customer Satisfaction And Loyalty for Customers With Varying Degrees of Service Expertise. International Journal of Service Industry Management, 9(1), 7-23.

Wibowo, A. (2015). Kajian Simulasi Desain Rambu Informasi Keselamatan di Tempat Wisata Pantai Parangtritis Berdasatkan Perilaku Budaya. Jurnal ITENAS Rekarupa, 3(1), 20088-5121.

Wibowo, L. A., \& Yuniawati, Y. (2007). The Influence of Tourist Product Attribute and Trust to Tourist Satisfaction and Loyalty A Study of Mini Vacation in Bandung. Ringkasan Hasil Penelitian Dosen.

Wiradiputra, F. A., \& Brahmanto, E. (2016). Analisis Persepsi Wisatawan Mengenai Penurunan Kualitas Daya Tarik Wisata terhadap Minat Berkunjung. Jurnal Pariwisata, 3(2), 129-137.

Yudistira, I. G. A. A., \& Susanto, A. (2012). Keselamatan Pengunjung Tempat Wisata. WIDYA, 29(320). 